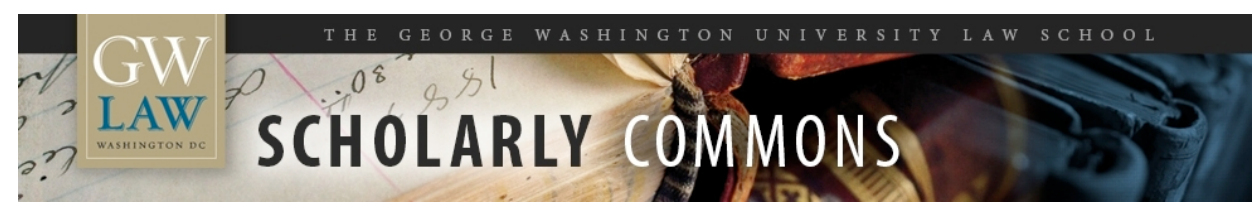

\title{
Accountability of Nongovernmental Organizations (NGOs) in Global Governance
}

Steve Charnovitz

George Washington University Law School, scharnovitz@law.gwu.edu

Follow this and additional works at: https://scholarship.law.gwu.edu/faculty_publications

Part of the Law Commons

\section{Recommended Citation}

Steve Charnovitz, Accountability of Non-Governmental Organizations in NGO Accountability: Politics, Principles and Innovations (Lisa Jordan \& Peter van Tuijl ed., Earthscan 2006).

This Article is brought to you for free and open access by the Faculty Scholarship at Scholarly Commons. It has been accepted for inclusion in GW Law Faculty Publications \& Other Works by an authorized administrator of Scholarly Commons. For more information, please contact spagel@law.gwu.edu. 


\title{
Accountability of Nongovernmental Organizations (NGOs) in Global Governance
}

\author{
Steve Charnovitz*
}

The issue of the accountability on nongovernmental organizations (NGOs) in global governance has received increased attention in recent years. The purpose of this paper is to analyze the issue, the consider whether any public problems exist, and to make recommendations on what should be done.

\section{The Historical Context}

Whenever an analyst begins a new study of an international policy problem, a reflection on how the problem has been analyzed in the past can be useful. An early consideration of NGO accountability is Rerum Novarum, the 1891 encyclical of Pope Leo XIII on Capital and Labor. ${ }^{1}$ Contrasting civil society with the "lesser societies," the encyclical states that the latter, the private associations, are "now far more common than before." 2 The encyclical offers ". . cheering hope for the future provided always that the associations We have described continue to grow and spread, and are well and wisely administered." 3 Although it concedes that the State should watch over these societies of citizens banded together in accordance with their rights, the encyclical says that the State "should not thrust itself into their peculiar concerns and their organization, for things move and live by the spirit inspiring them, and may be killed by the rough grasp of a hand from without." ${ }^{4}$ Taking

*George Washington University Law School. This paper was prepared for the Conference on Global Administrative Law, to be held at NYU Law School on 22-23 April 2005. CSteve Charnovitz, 19 April 2005.

${ }^{1}$ Rerum Novarum, 1891, available at http://www.vatican.va/holy_father.

${ }^{2}$ Id. paras. 51, 54 (emphasis added).

${ }^{3}$ Id. para. 55.

${ }^{4}$ Id. para. 55 . 
note in particular of societies of working men, but seemingly making a more general recommendation, the encyclical counsels that all such societies, "have the further right to adopt such rules and organization as may best conduce to the attainment of their respective objects. ${ }^{, 5} \mathrm{I}$ read this discussion as saying that although the private associations need wise self-administration, the state should have a light hand in overseeing them. The same sentiment was expressed decades earlier by Alexis de Tocqueville who in discussing potential government regulation of the ideas of associations, warned that "... a government can only dictate precise rules. It imposes the sentiments and ideas which it favors, and it is never easy to tell the difference between its advice and its commands." Although the term NGO was not in use in the 19th century, it did come into use at least as early as 1920. For example, in that year, Sophy Sanger used the term "non-government organisation" in a discussion of how such organizations had not been able to be present in 1906 during the first multilateral negotiations on labor treaties. ${ }^{7}$ Sanger contrasted this pre-war practice to the advent of the International Labour Organization (ILO) in 1919 which provided clear opportunities for the participation of "non-Government Delegates and advisers chosen in agreement with the industrial organisations, if such organisations exist, which are the most representative of employers or workpeople, as the case may be, in their respective countries."

A question regarding the selection of the ILO worker delegate from the Netherlands arose in the third (1921) session of the International Labour Conference when the Dutch government's choice was contested by the Netherlands Confederation of Trades Union. ${ }^{9}$ The Conference extended the

\section{${ }^{5}$ Id. paras. 55-56.}

${ }^{6}$ Alexis de Tocqueville, Democracy in America (Vol. 2, Part II, Chapter 5).

${ }^{7}$ Sophy Sanger, Practical Problems of International Labour Legislation, in E. John Solano (ed.), Labour as an International Problem 135, 136 (1920).

${ }^{8}$ Treaty of Versailles, art. 389.

${ }^{9} 1$ World Court Reports, Advisory Opinion No. 1, 113, 115. 
credential to the delegate chosen by the Dutch government, but asked the ILO Governing Body to request the Council of the League of Nations to seek an advisory opinion of the Permanent Court of International Justice (PCIJ) regarding this disagreement. This became the first matter to come before and be decided by the PCIJ which, in 1922, found no violation in how The Netherlands had made its selection. ${ }^{10}$ In considering the case before it, the Court welcomed oral statements from the International Labour Office and two international labor union federations. ${ }^{11}$ The openness of the PCIJ to statement by NGOs was an important episode in the history of the development of the NGO role in international law. If a similar question were to come to the International Court of Justice (ICJ) today, the ICJ would probably not allow NGO participation. No NGO participation in the ICJ has occurred since 1946 when the ICJ was established and the last requests by NGOs for an opportunity to submit amicus briefs in non-contentious cases were denied. ${ }^{12}$

The ILO Constitution is unusual in positing that the nongovernmental delegates are to be "representative" of organized constituencies within a country. Typically, the constitutions of international organizations that provide for NGO participation do not call for a representative body or suggest that the role of the NGO is to represent anyone in particular. For example Article 71 of the U.N. Charter states that "The Economic and Social Council may make suitable arrangements for consultation with non-governmental organizations which are concerned with matters within its competence." ${ }^{\prime 13}$ Thus, the stated rationale for the NGO being consulted is the concern of the NGO rather than its membership or representativeness.

\footnotetext{
${ }^{10}$ Id. at 121.

${ }^{11}$ Id. at 116.
}

${ }^{12}$ See generally Dinah Shelton, The Participation of Nongovernmental Organizations in International Judicial Proceedings, 88 AJIL 611, 624 (1994).

${ }^{13}$ U.N. Charter, art. 71. 
Nevertheless, when it implemented this provision in 1950, the U.N. Economic and Social Council established a set of principles among which was that the consulted organization "shall be of recognized standing and shall represent a substantial portion of the organized persons within the particular field in which it operates." ${ }^{14}$ This requirement, to a large extent, has been carried forward into the current ECOSOC credentialing rules, adopted in 1996. These rules state that the NGO "shall be of recognized standing within the particular field of its competence or of a representative character." ${ }^{15}$ These rules also state that "The organization shall have a representative structure and possess appropriate mechanisms of accountability to its members, who shall exercise effective control over its policies and actions through the exercise of voting rights or other appropriate democratic and transparent decision-making processes." ${ }^{\prime 16}$ Thus, the claim that an ideal NGOs is representative was contributed to the United Nations by governments not by overreaching NGOs.

A final important historical development that should be noted was the open attitude by the League of Nations toward NGOs. Recognizing that the League would be dealing with both semipublic bureaux (i.e., groups containing government members) and private associations on a daily basis, and seizing on the spirit of Article 24 of the League of Nations Covenant which, according to the Secretariat, required "that the League of Nations should follow closely and should encourage every international movement ...," the Secretariat began publishing a Handbook of International Organisations in $1921 .^{17}$ The Handbook was periodically updated and covered what we would today call intergovernmental organizations, transgovernmental networks, and NGOs. The handbook was

\footnotetext{
${ }^{14}$ Review of Consultative Arrangements with Non-Governmental Organizations, Resolution 288(X), 27 February 1950, para. 5.

${ }^{15}$ Consultative Relationship between the United Nations and Non-Governmental Organizations, Resolution 1996/31, para. 9.

${ }^{16}$ Id. para. 12.

${ }^{17}$ League of Nations, Handbook of International Organisations 9 (1921).
} 
organized with an excellent classification by function (e.g., "Politics and International Relations: Pacifism") and provided valuable information on each organization's address, year of organization, object, membership, governing body, finances, activities, and history. In my view, the initiative taken by the League in 1921 to publish this handbook was one of the most important intergovernmental acts in the 20th century to recognize the legitimacy of NGOs and to improve their transparency.

These episodes regarding community expectations as to the NGO role provide an illustrative window into the rich history awaiting scholars in the field and are not meant as a synoptic treatment of the overall historical context, which in any event would be far beyond the scope of this paper.

\section{The Contemporary Debate on NGO Accountability}

A good starting point for jumping into the contemporary debate on NGO accountability is the recent study by Ruth W. Grant and Robert O. Keohane on "Accountability and Abuses in World Politics." ${ }^{18}$ The authors identify two "theoretical models" or "basic concepts" of accountabilitydelegation and participation - that offer distinct answers to the question of who is entitled to hold power-wielders accountable. In the delegation model, the accountability holders are those who entrust or authorize power. In the participation model, the accountability holders are those affected by the actions of the power-wielders. Grant and Keohane conclude that both models are important, and that an effective accountability system should combine elements from both, and their analysis here is cogent and convincing.

Another important conclusion in their study is: "If governance above the level of the nationstate is to be legitimate in a democratic era, mechanisms for appropriate accountability need to be

\footnotetext{
${ }^{18}$ Ruth W. Grant \& Robert O. Keohane, Accountability and Abuses in World Politics, 99 APSR 29 (2005).
} 
institutionalized." Grant and Keohane catalog and evaluate the current accountability mechanisms for global power-wielders such as multilateral organizations, NGOs, transgovernmental networks, firms, and states. They find that in world politics, accountability for most power-wielders is likely to be less-constraining than optimal, but that the answer is not simply more accountability. Instead, the world needs "more intelligently designed accountability systems" that are sensitive to the variety of possible mechanisms and their shortcomings and sensitive to the normative claims of those affected by global entities. In that conclusion, I concur.

The authors make another very important point that I want to highlight. Grant and Keohane call for “... abandoning the belief that global accountability, to be genuine, must conform to abstract, maximal principles of democratic organization." They reach this conclusion in two steps: first, by admitting the difference between democratic nations, on the one hand, where there is a "clearly defined public" to provide responses to the fundamental questions about accountability, and the global level, on the other hand, where there is no public that can function in this way, and second, by stating that "There is no simple analogy that can be made between domestic democratic politics and global politics." In this way, they escape from the pessimistic trap laid by Professor Robert Dahl who applies a traditional democratic prism to international organizations and then concludes that a "democratic deficit" is an inevitable likely cost of all international government. ${ }^{19}$ Although Grant and Keohane admit that "democratic standards for accountability are not met at the global level," they claim that because the issue of accountability should not be narrowed to that of democratic control, it should be possible to improve accountability in world politics. I very much agree with that conclusion, and point out that it may not be inconsistent with Dahl's analysis as he seems to be addressing the democratic quality of international organizations rather than their accountability per se or the breadth or depth of participation within them.

\footnotetext{
${ }^{19}$ Robert A Dahl, Can International Organizations Be Democratic? A Skeptic's View, in Ian Shapiro \& Casiano Hacker-Cordón (eds.), Democracy’s Edges (1999) at 19, 34.
} 
Having noted some of the many points in Grant and Keohane's analysis on which I agree, let me now discuss some points of puzzlement or even disagreement starting with their definition of "accountability." The authors explain that accountability implies that certain actors have a triad of rights to: (1) hold other actors to a set of standards, (2) judge whether they have fulfilled their responsibilities in light of these standards, and (3) impose sanctions if they determine that these responsibilities have not been met. I am confused about both the standards and the sanctions.

With respect to standards, Grant and Keohane explain that accountability presupposes a relationship between the power-wielders and those holding them accountable where there is a "general recognition" of the legitimacy of the "operative standards for accountability" or the "accepted standards for behavior." ${ }^{20}$ This definition links the availability of accountability to a recognition or pre-supposition of clear standards - a condition that sometimes may exist (e.g., accounting standards) yet often does not. In my view, the term "accountability" is often used in a wider sense than this definition - that is, to include situations where the power-wielder may not have accepted any clear standard shared by the community that may assert an accountability claim. If I am right about that, then either the term accountability needs to be more broadly defined, or we may need to add another term to the debate to capture the claims that do not have standards. For example, one might discuss the responsibility of power-wielders to those who are affected by their decisions.

As I read Grant and Keohane, however, they are discussing "accountability" beyond the instances where standards exist, as they define them. To give one example, Grant and Keohane state that "the process of democratic elections can be endorsed readily as an effective mechanism for accountability ...." Although elections provide for assessment and choice, surely no substantive standards exist for the way that the accountability holders - namely, the voters - decide who to vote for. Each voter makes her decision individually based on her own frame of reference. Elections do

\footnotetext{
${ }^{20}$ Grant $\&$ Keohane, supra note 18 , at $29-30$. They also suggest that an accountability process requires "prior obligations." Id. at 30.
} 
not require an agreement among voters as to the appropriate standard for judgment and certainly do not require that politicians know in advance, and/or concur with, a discrete set of standards that will be used. Thus, while I agree with Grant and Keohane that constitutional democratic governments "are accountable to their citizens," such accountability, in my view, does not spring from judgments based on jointly-agreed standards.

One implication of the actual way in which they use the term "accountability" is that the absence of standards in many global governance decisions is not a reason to deny the possibility of achieving accountability. If I am right about that, then there would not be any need to add another term to the debate.

Another puzzling example of how Grant and Keohane use the term "standard" involves the World Trade Organization (WTO). They claim that WTO attention in the Doha Round to agricultural subsidies demonstrates an "accountability process" because the WTO "has been moving, haltingly, toward restricting agricultural subsidies" through "policies [that] reflect prevailing norms insofar as they have are accepted by powerful governments ...." To them, this episode "illustrates the importance of standards of behavior." Leaving aside the question of whether the WTO should be considered a purposive actor (an issue I address elsewhere), the negotiations on agricultural subsidies are hardly the application of a standard of behavior to subsidizing governments. To the extent that the current standard of behavior in WTO rules restricts agricultural subsidies, that standard can be enforced through dispute settlement outside the Doha Round. ${ }^{21}$ What is occurring in the Doha Round

\footnotetext{
${ }^{21}$ Thus, the other point made that Grant and Keohane make about the WTO is on target. They observe that states have delegated to the WTO powers of supervisory accountability over their own trade actions. Grant \& Keohane, supra note 18, at 39. The term "accountability" here is used consistently with their definition because the supervisory role of WTO dispute settlement is based on pre-agreed standards as to the review process and the substantive law to be applied. My one reservation is that I do not agree that states truly delegate supervisory accountability. A state cannot delegate authority that it does not possess and in the absence of the WTO or other trade treaty, there is no inherent authority of one state to supervise or hold others accountable for their official trade actions. Grant and Keohane acknowledge this in their analysis. See id. at 30.
} 
is that governments are discussing a change in trade rules that would alter the current standards of behavior and update the prevailing international norms. The many NGOs that are supporting new WTO disciplines on agricultural subsidies may view their efforts as making the WTO more accountable to the needs of the poor, but I would doubt that they view their advocacy as holding the WTO or its member governments to a pre-established standard of conduct.

I am also puzzled by the way that Grant and Keohane use the term "sanction." They see sanctions available at the domestic level and contrast that to the international level where they find that "sanctions main the weak point in global accountability ...." They emphasize that "the principal means in domestic democracies of participatory sanctions-elections - is not available on a global basis.” While I agree that elections are not global, I disagree with the author's assumption that elections are sanctions. Whatever else might be said about Election Day 2004 (November 2) in the United States, it was hardly the national day of sanction! In my view, elections in the United States provide the public a chance to choose their representatives for the next term and to decide various referenda. If Smith replaces Jones as the congressman, I do not think that Jones has been sanctioned in the usual sense of the word. By viewing elections as the accountability sanction, Grant \& Keohane set a precondition for accountability that will unnecessarily make the international level appear less accountable than the national level.

Another concern I have is that Grant and Keohane are too quick to contrast the international level characterized by "the absence of a coherent and well-defined global public" with the domestic or national level where "those affected by the power-wielders are generally understood to be those subject to the law of the polity, so it is fairly easy to determine who has a right to participate." In my view, the appropriate public is not always well-defined in any territory or at any level of governance. Consider a few questions from the United States: Should felons have a right to vote? Should residents of the District Columbia or Puerto Rico have voting representation in Congress? Should 
non-residents of New York who have to pay taxes in New York have the right to vote in New York $?^{22}$

Or how about Congressman Tom DeLay, the Majority Leader of the U.S. House of Representatives and frequent target of public criticism. DeLay is a Member of Congress because he was elected by his district and in particular by the 149,901 citizens who voted for him in 2004 .. He is Majority Leader because he was elected without opposition in the House Republican Conference. DeLay's democratic legitimacy cannot be contested as a matter of law, but one could argue that with so many people in the United States being affected by DeLay, the relevant public to decide whether he should have so much power is broader than the 149,901 individuals who voted for him in the 22nd Congressional district of Texas and the 231 House members who did so in Washington. Appearing on ABC's "This Week" on 10 April 2005, Senator Rick Santorum defended DeLay explaining that "Now you may not like some of the things he's done.... That's for the people of his district to decide, whether they want to approve that kind of behavior or not." In my view, while Santorum properly states U.S. Constitutional law and practice, it does not take much imagination to perceive a broader community in the United States that is being disenfranchised from being able to directly act against DeLay's abuses of power.

Grant and Keohane ask the central question: "Who is entitled to hold power-wielders accountable for abuses?," and they provide a useful answer by identifying and examining seven accountability mechanisms in world politics. In my view, there is an even broader question that should be considered which is who is entitled to influence the use of power and authority at the global level, or for that matter any level of governance. Grant and Keohane state that in world politics today, "there is no juridical public on a global level" and "no sociological global public," and that "a genuine global public comparable to publics in well-established democracies does not exist."

\footnotetext{
${ }^{22}$ See Tony Mauro, N.Y. Appeals Court: Telecommuter Must Pay State Tax, The Legal Intelligencer, 31 March 2005, at 4.
} 
That conclusion may well be true, but in my view, Grant and Keohane do not give sufficient attention to the basic unit of the public, any level of governance, which is the individual sentient human being.

Considerations of public control of authority and power should begin with the individual, and because I start with that assumption, I believe that the current debate about accountability in global governance should give more attention to the important contributions of Myres S. McDougal and Harold D. Lasswell. In their 1959 article in the American Journal of International Law, "The Identification and Appraisal of Diverse Systems of Public Order," McDougal and Lasswell describe a "world social process" in which the participants "are acting individually in their own behalf and in concert with others ...."23 They emphasize that "The ultimate actor is always the individual human being who may act alone or through any organization," and note in particular "associations which "do not concentrate upon power but primarily seek other values." ${ }^{24}$ Attention to the role of private associations is one of many ways in which McDougal and Lasswell anticipated the current debate about NGOs.

By starting with the individual, McDougal and Lasswell avoid two analytical traps that many commentators get stuck in. First, because individuals are seen as the active participants, the world social and power process can be viewed as "expanding circles of interaction" or as a "series of arenas ranging in comprehensiveness from the globe as a whole ... to nation states, provinces and cities, on down to the humblest village and township. ${ }^{.25}$ In this analytical approach, there is no need to explain why individuals should be able to participate at broader (higher) levels of decisionmaking just as they do in narrower (lower) levels. Second, in positing the expanding circles, McDougal and Lasswell

\footnotetext{
${ }^{23}$ Myres S. McDougal \& Harold D. Lasswell, The Identification and Appraisal of Diverse Systems of Public Order, 53 AJIL 1 (1959) at 7.

${ }^{24}$ Id. at 8. More recently, Tom Franck has given careful attention to the role of autonomous individuals in national and international law. See Thomas D. Franck, The Empowered Self (1999).

${ }^{25}$ McDougal \& Lasswell, supra note 23, at 7, 8.
} 
avoid the "impossible separation of national and transnational law." ${ }^{26}$ The jurisprudence of human dignity they propose is applicable to all levels.

In my view, the notion of the individual being governed in a multitude of arenas is empirically convincing and normatively valuable. On any given day, the individual may be confronted with the dictates and decisions of his homeowner community, employer, local government, provincial government, national government, and international organizations. The distance between the individual and his homeowner community may be closer than the distance to the United Nations, but the ability of the individual to influence any of the authoritative decisions may be very limited. Consider, for example, the innocent victims who suffer collateral damage as a result of sanctions ordered by the U.N. Security Council. ${ }^{27}$ Or the plight of Prince Charles and Camilla Parker Bowles who after seemingly squaring their plans to marry in Windsor Castle with the dictates of Church and State, were forced to change the venue to Windsor's town hall after learning that the relevant ordinance would have required that the Castle be open for public marriages during the next three years. ${ }^{28}$ Or the individuals dying of fatal illnesses who are being denied potentially effective drug treatments due to precaution by the U.S. Food and Drug Administration. ${ }^{29}$ Or the women trying to fill prescriptions for legal drugs who are being frustrated by pharmacists who use their delegated

\footnotetext{
${ }^{26}$ Harold D. Lasswell \& Myres S. McDougal, Jurisprudence for a Free Society (1997) at 32.

${ }^{27}$ See August Reinisch, Developing Human Rights and Humanitarian Law Accountability of the Security Council for the Imposition of Economic Sanctions, 95 AJIL 851 (2001). On the evolving function of the Security Council, see Stefan Talmon, The Security Council as World Legislature, 99 AJIL 175 (2005).

${ }^{28}$ Ben English, Charles and Camilla Must Move Their Wedding After a Legal Blunder, The Advertiser, 19 Feb. 2005, at 7.

${ }^{29}$ David M. Minor M.D., Dying While Waiting for the FDA To Act, Wall Street Journal, 15 April 2005.
} 
authority as medical gatekeepers to refuse to fill prescriptions that offend the pharmacist's sense of morality. ${ }^{30}$

The normative value of seeing the individual as the object of simultaneous, multiple levels of lawmaking is that the truth becomes self-evident that the individual will have an interest in influencing all of the authoritative decisions that affect him, including not only those made by officials that he has elected but also decisions made by others. From the perspective of the individual, the webs of authority enveloping him may be distinct in some ways, but share a common imperfection in sometimes not allowing the individual to achieve his interests and promote his own conception of a just community order. Grant and Keohane urge caution against the "simple analogy that can be made between domestic politics and global politics." They are right that no simple analogy will be sufficient. Yet from the perspective of individual, the need to engage in politics is omnipresent, and although the strategies one uses in various political arenas will likely differ, the moral justification for action may be unified.

Even though the debate about NGO participation in global governance is often simplified to the question of the proper and legitimate role of those bodies, one should not forget that the source of legitimacy for an NGO begins with the individual who uses it as an instrument of voluntary association. $^{31}$ Although most of the international legal agreements that provide for public participation in international organizations extend that participation to NGOs rather than to individuals, one prominent exception in the World Bank Inspection Panel that permits requests for inspection from "any group of two or more people in the country where the Bank-financed project is located who believe that as a result of the Bank's violation their rights or interests have been, or are

\footnotetext{
${ }^{30}$ Ellen Goodman, Pharmacists Should Dispense Drugs, Not Morality, Deseret Morning News, 9 April 2005; Monica Davey \& Pam Belluck, Pharmacies Balk on After-Sex Pill and Widen Fight, N.Y. Times, 19 April 2005, at A1.

${ }^{31}$ Pope Leo XIII traces the idea back to Ecclesiastes (4:9) ("It is better that two should be together than one; for they have the advantage of their society."). Rerum Novarum, supra note 1, para. 50.
} 
likely to be adversely affected in a direct and material way." ${ }^{, 2}$ The Inspection Panel is a good example of a clear accountability mechanism for an international organization because the Panel reviews whether the Bank's actions are consistent with the Bank's own standards.

This discussion provides context for the topic of this paper which is how to think about and evaluate the accountability of NGOs. In particular, who should NGOs be accountable to? How should they be made accountable and does that accountability properly differ from the accountability expected for other power-wielders? Do the myriad functions of NGOs suggest the need for slicing up the analysis to look separately at these functions?

How one analyzes accountability will be connected to the issue of what role is legitimate for NGOs in global governance. There can be a tension between the power that NGOs have and the accountability in place for the use of that power. Moreover, the perceived need for accountability may grow insofar as one perceives the legitimacy of NGO participation to be questionable.

Grant and Keohane offer some importance insights regarding NGO accountability, a problem that they see arising because NGOs are among the "powerful entities" in "world politics." 33 Let me highlight five of their points. First, like other some power-wielders such as states, NGOs acquired their power without delegation or authorization by entities even remotely representative of the world population as a whole. ${ }^{34}$ Even without delegated authority, however, "transnational civil society" may articulate standards by which other power-wielders may be held accountable. ${ }^{35}$ Second, the task

\footnotetext{
${ }^{32}$ Laurence Boisson de Chazournes, The World Bank Inspection Panel: About Public Participation and Dispute Settlement, in Tullio Treves et al. (eds.), Civil Society, International Courts and Compliance Bodies 187 (2004).

${ }^{33}$ See Grant \& Keohane, supra note 18 , at 30.

${ }^{34}$ Id. at 33. But some exceptions exist. For example, various components of the Red Cross movement have explicit or implied authority under Geneva Convention of 1949, arts. 3, 9, 26, 44. Another example is the U.N. Security Council which occasionally requests NGOs to provide assistance. See, e.g., Complaint of Aggression Upon the Republic of Korea, Res. 85 (31 July 1950).

${ }^{35}$ Grant \& Keohane, supra note 18 , at 35.
} 
of assessing accountability on a global scale differs from making assessments on a national scale. If an international organization or NGO is to be judged by its global accountability, then the same reference point should apply to the state. Grant and Keohane cite Andrew Moravcsik's observation that critics of the EU compare it to the ideal democracy standing alone rather than to the "actual functioning of national democracies adjusted for its multi-level context. ${ }^{{ }^{36}}$ With respect to states, Grant and Keohane suggest that "domestic democracy is insufficient" and that "democratic states will act in a biased way toward noncitizens." Third, they argue that "international NGOs are not legitimated by ties to a defined public." Fourth, they argue that "In practice, few NGOs have welldefined procedures for accountability to anyone other than financial contributors and membersquite a small set of people." On the other hand, however, Grant and Keohane take note of the forms of accountability that sometimes do exist for some NGOs such as fiscal accountability to donors, a market accountability to donors, a reputational accountability to the public, and peer accountability. ${ }^{37}$ Fifth, they recommend that NGOs must become "increasingly transparent if they are to remain credible."

Over the past decade, the question of the role and accountability of NGOs in world affairs has been given a great deal of attention by both the critics of NGOs and their defenders. Perhaps the sharpest critic is Kenneth Anderson who does not even get to the issue of enhancing NGO accountability because he is so opposed to the NGO role. ${ }^{38}$ Anderson argues that international NGOs

\footnotetext{
${ }^{36}$ Grant $\&$ Keohane, supra note 18 , at 37 (emphasis added).

${ }^{37} \mathrm{NGOs}$ seeking to retain support from the public recognize the need for transparency and donor accountability. A good example is the Todd M. Beamer Foundation, set up after September 11, that has prepared a colorful, informative 2004 annual report and posted it on the foundation's website. See http://www.heroicchoices.org.

${ }^{38}$ Kenneth Anderson, The Limits of Pragmatism in American Foreign Policy: Unsolicited Advice to the Bush Administration on Relations with International Nongovernmental Organizations, 2 Chicago Journal of International Law 371 (2001). With regard to international NGOs, Anderson says "their hubris exceeds their accountability" Id. at 388.
} 
are not the equivalent of civil society in a settled democratic society and thus their participation in international processes is harmful in two respects. ${ }^{39}$ At the domestic level, NGOs can act as protest and pressure organizations but their actions are not viewed as part of the democratic accountability process. ${ }^{40}$ Yet at the international level not featuring direct elections, NGOs offer themselves as substitutes for democracy, according to Anderson. This participation can be disadvantageous because it will make it "ever more difficult to confront the naked and painful consequences of an international system that has no democratic legitimacy." ${ }^{41}$ The second negative result from NGO international activism, according to Anderson, is that by refusing to conform to the results of a democratic process within a state and instead pursuing contrary results internationally, NGOs "seek to undermine the processes of democracy within democratic states ...," and "many international NGOs are hostile to the very idea of democracy if its results might conflict with their desired results . $\ldots{ }^{42}$ Thus, according to Anderson, international NGOs, unlike their domestic counterparts, are not only "undemocratic," but actually are "profoundly antidemocratic." ${ }^{43}$ Anderson does not explain exactly why international NGOs are undemocratic other than to refer approvingly to the question asked by David Rieff, namely, "So who elected the NGOs?". ${ }^{44}$ Happily, in addition to the general study by Grant and Keohane, there is now a specific literature on NGO accountability that I will briefly survey.

\footnotetext{
${ }^{39}$ Id. at 382.

${ }^{40}$ Id. at 382.

${ }^{41}$ Id. at 382.

${ }^{42}$ Id. at 383, 386.

${ }^{43}$ Id. at 383.
}

${ }^{44}$ See id. at 379. 
Peter Spiro has sought to unpack NGO accountability by asking to whom the accountability can be developed. ${ }^{45}$ His answer is that NGOs should be accountable both to their constituencies and to process, and he frames that distinction as internal versus external accountability. Regarding internal accountability to members, he suggests that the problem of accountability is exaggerated because there are practical constraints on NGOs (such as membership) that keep them in line. In evaluating NGO internal accountability, he cautions against the "fetishization of other forms of association," such as the democratic state, which is "implicitly idealized on the accountability metric, especially by virtue of periodic elections." ${ }^{46}$ In Spiro’s view, voting is a "crude tool for keeping governmental authorities in line" and "[g]overnments can get away with an awful lot before having to answer to their memberships . .." Regarding external accountability of NGOs to "the system," Spiro contends that it is now suboptimal because given the present informal arrangements for NGO participation, NGOs lack incentives to be accountable. Spiro's proposed solution is for states to accept "formal inclusion of non-state actors in international decisionmaking" in order to "hold NGOs, as repeat players, accountable to international bargains." $" 48$

Paul Wapner emphasizes comparative analysis in considering the accountability of NGOs visà-vis the accountability of governments. ${ }^{49}$ He finds the "gap between citizen concerns and government action" to be "wide," and notes that states are not perfectly accountable externally at the international level. ${ }^{50}$ He does not claim that NGOs are more accountable than states, but rather that NGOs are differently accountable. He points out various ways in which NGOs are accountable: They

\footnotetext{
${ }^{45}$ Peter J. Spiro, Accounting for NGOs, 3 Chicago J. Int'1 Law 161 (2002).

${ }^{46}$ Id. at 164.

${ }^{47}$ Id. at 164 .

${ }^{48}$ Id. at $162,167$.

${ }^{49}$ Paul Wapner, Defending Accountability in NGOs, 3 Chi. J. Int'1 L. 197 (2002).

${ }^{50}$ Id. at 199-200.
} 
are accountable to members through exit and pocketbook, accountable to directors, accountable through NGO collaboration with other NGOs (the phenomenon that Grant and Keohane refer to as "peer accountability"), and accountable to states when NGOs seek to gain accreditation to international organizations. He also points out that international-minded NGOs may have broader aspirations than states in seeking to promote the interests of a global citizenry in a "sovereignty-free" way. ${ }^{51}$

Benedict Kingsbury explains that the struggle to articulate a useful approach to establishing "rigorous accountability of non-states actors suggests that international civil society has at present minimal conceptual resources other than First Amendment liberalism for structuring thought about problems of accountability." ${ }^{52}$ Yet First Amendment liberalism, according to Kingsbury, offers few means of NGO accountability except via markets, and it tends to view demands for other forms of accountability with suspicion. Moreover, First Amendment liberalism is not very helpful in addressing the participatory claims of ascriptive groups, such as indigenous peoples exercising governmental powers. Kingsbury calls for the development of "[a] richer international constitutionalism" to help address accountability, mandate, representation, and participation. ${ }^{53}$

Ann Florini states that there are "troubling questions about legitimacy and accountability" of transnational civil society, and she argues that such questions need to be addressed. ${ }^{54}$ In particular, she calls for greater transparency about personnel, operations, funding sources and expenditures, and purposes, and further states that governments should require reporting on funding sources and

\footnotetext{
${ }^{51}$ Id. at 203-204 (quoting James Rosenau).

${ }^{52}$ Benedict Kingsbury, First Amendment Liberalism as Global Legal Architecture: Ascriptive Groups and the Problems of the Liberal NGO Model of International Civil Society, 3 Chicago J. Int'1 L. 183, 186 (2002).

${ }^{53}$ Id. at 183 .

${ }^{54}$ Ann M. Florini, Lessons Learned, in Florini (ed.), The Third Force. The Rise of Transnational Civil Society 211, 232 (2000).
} 
expenditures. She also points out that the problem of accountability is to some extent self-correcting because "[o]ver time, groups whose facts and arguments prove unfounded discredit themselves. ${ }^{" 55}$

Michael Edwards is one of the world's most thoughtful and experienced analysts of the NGO role in global governance. Edwards explains that "NGO accountability is weak and problematic, since there is no clear 'bottom line' for results and no single authority to which NGOs must report on their activities. ${ }^{, 56}$ Edwards advocates a "New Deal" in which more participation in global governance is granted "in return for transparency and accountability on a set of minimum standards for NGO integrity and performance, monitored largely through self-regulation" plus a "much larger array of voluntary regulations and other, non-coercive means of influencing destructive behavior. ${ }^{, 57}$ Greater accountability, in Edwards's view is needed both upward, to donors, and downward, to the poor. $\mathrm{He}$ also calls for measures to level the playing field among NGOs by providing additional support for Southern NGO participation. Another constructive suggestion is for fostering innovation in global governance through "a period of structured experimentation in NGO involvement."

Debra Spar and James Dail identify an accountability gap for measures of NGO performance. ${ }^{59}$ They propose an interesting central product classification (or typology) of NGO functions (e.g., refugee assistance and health services) and then discuss the work of Alan Fowler who has proposed that NGOs be assessed by their outputs, outcomes, and impact. ${ }^{60}$ Spar and Dail favor

\footnotetext{
${ }^{55}$ Id. at 234.

${ }^{56}$ Michael Edwards, NGO Rights and Responsibilities 19 (2000).

${ }^{57}$ Id. at 4-5, 13 (emphasis deleted).

${ }^{58}$ Id. at 32 .

${ }^{59}$ Debra Spar \& James Dail, Of Measurement and Mission: Accounting for Performance in NonGovernmental Organizations, 3 Chicago J. Int'l L. 171 (2002).

${ }^{60}$ Id. at $175,177$.
} 
Fowler's approach, which is both qualitative and quantitative, saying that this approach "asks that NGOs deliver results without specifying precisely what those results need to be." ${ }^{61}$

Hugo Slim has proposed a working definition of NGO accountability which is "the process by which an NGO holds itself openly responsible for what it believes, what it does and what it does not do in a way which shows it involving all concerned parties and actively responding to what it learns." ${ }^{62}$ Slim advises that this process begin by constructing a map of the NGO's various stakeholders in a given situation because NGO accountability cannot be expected to be uniform across a wide range of NGO activity. The map may reveal conflicting interests and will help design the right accountability mechanisms such as social audits, a complaint procedure, etc.

Writing in 2000, Gary Johns raised concerns about some of the assumptions underlying the NGO accountability movement. ${ }^{63}$ Johns argues that when NGOs posit that they are a new form of democratic legitimacy or the greatest expression of democracy, then NGOs may become subject to "a policy of heavy-handed regulation of private associations." ${ }^{64}$ Johns sees this path as undesirable from a liberal perspective, and suggests that each NGO should "claim no more than to represent a view" and should not seek to belittle the authority of representative democracy. ${ }^{65}$ In his view, the only scrutiny needed for NGOs is "the ordinary scrutiny of any group or person who seeks to make claims on the public," that is, the "integrity and truth of the proposal."

\footnotetext{
${ }^{61}$ Id. at 178 .
}

${ }^{62}$ Hugo Slim, By What Authority? The Legitimacy and Accountability of Non-governmental Organisations, Journal of Humanitarian Assistance, 2002, available online.

${ }^{63}$ Gary Johns, NGO Way to Go. Political Accountability of Non-government Organizations in a Democratic Society, IPA Backgrounder, Nov. 2000,

${ }^{64}$ Id. at $3,14$.

${ }^{65}$ Id. at 2.

${ }^{66}$ Id. at 5. See Edwards, supra note 56, at 28 (“And NGOs should not, as a general principle, be held to higher standards of behaviour than any other institution."). 
A heightened interest in achieving greater accountability of NGOs has been in the air for several years. For example in 2003, the New York Times editorialized that ... nongovernmental organizations, or NGO's, are now part of the power structure, too. They receive donations from the public and advocate policies that each group claims are in the public interest. As they become part of the established political landscape worldwide, these groups owe it to the public to be accountable and transparent themselves." 67

Following that same theme, The Economist ran an influential essay "Who Guards the Guardians?" which put forth the "novel idea" of "auditing NGOs." 68 Actually The Economist has been more attentive to the phenomenon of NGOs than any other general interest journal. In 2000, The Economist noted that NGOs ". . . can get into bad ways because they are not accountable to anyone." ${ }^{99}$ In 2003, the Capital Research Center Foundation Watch published an article on "NGO Accountability" by Robert Huberty and David Riggs who lamented that many NGOs are "using their power to undermine individual freedom ... [by] promoting new international arrangements that are indifferent to the U.S. Constitution ...."70 Huberty and Riggs make several recommendations including a clear distinction between charitable and political activity, full disclosure of all government funding of NGOs, and an encouragement to NGOs to publish annual reports and make them available over the internet.

Attention to the alleged lack of NGO accountability has, not surprisingly, led to serious introspection by NGOs, and stepped-up efforts at setting standards for, and appraising and auditing

\footnotetext{
${ }^{67}$ Holding Civic Groups Accountable, New York Times, 21 July 2003, at A18.

${ }^{68}$ Who Guards the Guardians, The Economist, 20 September 2003.

${ }^{69}$ Sins of the Secular Missionaries, The Economist, 29 January 2000. This article ended with the puzzling suggestion that "The chief aim of NGOs should be their own abolition." See also The Nongovernmental Order, The Economist, 11 December 1999,

${ }^{70}$ Robert Huberty and David Riggs, NGO Accountability: What the U.S. Can Teach the U.N., Foundation Watch, July 2003.
} 
NGOs by academics, governments, foundations, and other NGOs. For example in 2003, the Humanitarian Accountability Partnership International (HAP-I) was launched to help monitor the actions of those engaged in humanitarian activities. ${ }^{71}$ The HAP-I promotes and assists self-monitoring by member organizations which include well-known organizations such as CARE International and the Danish Refugee Council. The most interesting development has been the establishment of NGOs to monitor other NGOs. For example, the American Enterprise Institute and the Federalist Society for Law and Public Policy Studies have jointly set up "NGO Watch" in "an effort to bring clarity and accountability to the burgeoning world of NGOs . . . " 72 The web site is largely composed of news stories, related documentation, and policy papers. A recent posting, for instance, reports that Afghanistan President Hamid Karzai issued a "stinging rebuke" to NGOs for "squandering the previous resources that Afghanistan received in aid from the international community." Another effort, the NGO Monitor Project, was set up to examine how certain humanitarian NGOs covering Israel and the Middle East deviate from their mission. ${ }^{73}$ This Project is a joint venture of the Institute for Contemporary Affairs and B'nai B'rith International. Another NGO that is focusing on accountability is One World Trust. In 2003, One World Trust published a "Global Accountability Report" that applied the same standards to assess several intergovernmental organizations, transnational corporations, and nongovernmental organizations. ${ }^{74}$ The Report defines accountability as "a process by which individuals or organizations are answerable for their actions and the consequences that follow from them." ${ }^{, 75}$ The Report points to eight dimensions of accountability

\footnotetext{
${ }^{71}$ See www.hapinternatinoal.org.

${ }^{72}$ See www.ngowatch.org.

${ }^{73}$ See www.jcpa.org.

${ }^{74}$ Hetty Kovach et al., Power Without Accountability? (One World Trust, 2003), available at www.oneworldtrust.org.

${ }^{75}$ Id. at 3 .
} 
including four internal dimensions and four external ones. One might also note that attention to NGO accountability comes at a time of enhanced attention to the need for greater accountability of everyone and everything including corporations, religious leaders, news bureaus, schools, and parliamentarians. ${ }^{76}$

In early 2005, the Consultative Board to the WTO Director-General discussed in general terms the issue of NGO accountability. ${ }^{77}$ The Board noted the criticism that "those lobbying for more access" are "often neither especially accountable nor particularly transparent themselves." 78 Furthermore the Board stated:

While there is now a broad recognition among member states of the UN of the substantial and proven benefits of non-governmental participation in intergovernmental debate on global issues, there are continuing concerns about the legitimacy, representativity, accountability and politics of non-governmental organizations. There is also a serious imbalance in the capabilities of nongovernmental organizations from developed and developing countries. ${ }^{79}$

Another expert group that recently gave attention to the issue of NGO accountability was the Panel of Eminent Persons on United Nations-Civil Society Relations, appointed by SecretaryGeneral Kofi Annan. In its report of June 2004, the Panel suggested that in its practices for engaging civil society, the United Nations should work to define “. . . standards of governance, such as those for transparency and accountability." In particular, according to the Panel, the U.N. Secretariat

\footnotetext{
${ }^{76}$ See, e.g., the independent investigation of CBS and 60 Minutes, January 2005, available at http://wwwimage.cbsnews.com/htdocs/pdf/complete_report/CBS_Report.pdf and Larry Kudlow \& Eileen Norcross, A Sarbanes-Oxley for Congress?, Wall Street Journal, 15 April 2005, at A10.

${ }^{77}$ The Future of the WTO, Report of the Consultative Board to the Director-General Supachai Panitchpakdi, January 2005 (known as the Sutherland Report).

${ }^{78}$ Id. para. 199.

${ }^{79}$ Id. para. 209.
} 
should discuss with the private groups advising the UN "possible codes of conduct and self-policing mechanisms to heighten disciplines of quality, governance and balance." ${ }^{" 80}$

Aside from occasional U.N. Security Council sanctions, the most ambitious intergovernmental supervision of NGOs that has come to my attention occurs in the WTO Agreement on Technical Barriers to Trade (TBT). This provision, which applies only to a narrow swath of NGOs, directs governments to "take such reasonable measures as may be appropriate to them to ensure that local government and non-governmental standardizing bodies within their territories ... accept and comply" with the TBT Code of Good Practice for the Preparation, Adoption and Application of Standards. ${ }^{81}$ Among the requirements of the Code are that governmental and nongovernmental standardizing bodies shall:

-Play a full part in relevant international standardizing bodies with participation, whenever possible, taking place through one delegation representing all standardizing bodies in the territory. ${ }^{82}$

- Make every effort to achieve a national consensus on the standards to be developed. ${ }^{83}$

-Publish a work program at least once every six months. ${ }^{84}$

- Before adopting a standard, allow a period of at least 60 days for the submission on comments by interested parties within the territory of that Member. ${ }^{85}$ Take any submitted comments into account and, if so requested, reply to them as promptly as possible. ${ }^{86}$

- Make an objective effort to resolve any complaints submitted by other standardizing bodies that have accepted the Code. ${ }^{87}$

\footnotetext{
${ }^{80}$ We the Peoples: Civil Society, the United Nations and Global Governance, Report of the Panel of Eminent Persons on United Nations-Civil Society Relations, A/58/817, June 2004, at 59.

${ }^{81}$ Agreement on Technical Barriers to Trade (TBT), art. 4.1.

${ }^{82}$ TBT Agreement, Annex 3, Code of Good Practice for the Preparation, Adoption and Application of Standards, para. G.

${ }^{83}$ Id. para. H.

${ }^{84}$ Id. para. J.

${ }^{85}$ Id. para. L.

${ }^{86} \mathrm{Id}$. para N.
} 
Pursuant to its authority under the TBT Agreement, the TBT has adopted a Decision that provides additional principles for the elaboration of international standards. ${ }^{88}$ The Decision calls on international standardizing bodies to be open to the relevant bodies of all WTO Members and to provide participants, especially from developing countries, with "meaningful opportunities to participate at all stages of standard development." ${ }^{, 89}$ So far, little has been done in the WTO to police these rules.

The party with potential culpability at the WTO would be the WTO Member(s) with the errant nongovernmental standardizing body in its territory. ${ }^{90}$ The NGO itself would not be subject to WTO dispute settlement even if it agrees to accept the Code of Good Practice. In general, the WTO adheres to a principle of Member responsibility in which dispute settlement is always between governments and is directed at the government that is alleged to have violated WTO rules.

As far as I am aware, the only exception to this principle occurs in the WTO Agreement on Preshipment Inspection (PSI) in which a private party, either the preshipment inspection entity or the exporter, may lodge a dispute to a special panel of experts established by the Independent Entity, with the decision of the panel deemed as binding. ${ }^{91}$ No such disputes have yet been raised. This PSI provision has interesting implications with respect to the development of global administrative law as

\footnotetext{
${ }^{87}$ Id. para. Q. This rule seems to include complaints by bodies in other countries.

${ }^{88}$ TBT Committee, Decisions and Recommendations Adopted by the Committee Since 1 January 1995, G/TBT/1/Rev.8, 23 May 2002, at 26 providing the Decision of the Committee on Principles for the Development of International Standards, Guides and Recommendations with relation to Articles 2, 5 and Annex 3 of the Agreement. This Decision and its implications are discussed in Steve Charnovitz, International Standards and the WTO, May 2002, available in GWU Law School Legal Studies Research Paper No. 133 (on SSRN).

${ }^{89}$ Decision of the Committee, ibid., at paras. 6, 7.

${ }^{90}$ TBT Agreement, arts. 4.1, 14.1 (requiring that trade interests be significantly affected).

${ }^{91}$ Agreement on Preshipment Inspection, art. 4.
} 
does another anomalous WTO provision, Article 8.5 of the Agreement on Subsidies and Countervailing Measures (SCM). Under Article 8.5, a WTO member may gain "binding arbitration" regarding a number of issues, one of which is a review of a decision made by WTO Committee on Subsidies and Countervailing Measures regarding whether the conditions for a non-actionable subsidy have been met in a particular instance..$^{2}$ This form of administrative review is unusual because it provides for an independent reconsideration of a decision made by a WTO Committee composed all of WTO members. This provision was not used during the first five years of the WTO and the entire SCM Article 8 was sunsetted at that point.

Looking ahead, the development of an overall strategy for enhancing NGO accountability should consider not only the recent developments in practice, but also the projected trends. ${ }^{93}$ The most sophisticated study that has come to my attention is "The 21 st Century NGO," a report prepared by Sustainability, a strategy consultant. ${ }^{94}$ The Report compares 20 th and 21 st century NGOs, and suggests that the latter will be insiders rather than outsiders, will focus on solutions rather than problems, will invest heavily in networks, will seek support as a good investment rather than playing on guilt, will be multi-dimensional rather than single-issue campaigns, and will "adopt best practice in transparency, accountability and governance." 95 In its chapter on NGO governance, the report rates the quality of the information provided in the annual reports of 10 well-known NGOs. ${ }^{96}$ The top performer was CERES which created the CERES principles for corporate environmental conduct and established the Global Reporting Initiative, which includes an international standard for monitoring

\footnotetext{
${ }^{92}$ Agreement on Subsidies and Countervailing Measures (SCM), arts. 8.4, 8.5.

${ }^{93}$ See McDougal \& Lasswell, supra note 23, at 14-15.

${ }^{94}$ See The 21 st Century NGO in the Market for Change, undated, available at www.sustainability.com.

${ }^{95}$ Id. at 2.

${ }^{96}$ Id. at 24.
} 
corporate performance on a "triple bottom line" of economic, social, and environmental performance. ${ }^{97}$ Thus, we see one NGO giving high marks to another well-known NGO that evaluates corporate performance. Another recommendation in "The 21st Century NGO" is that funders of NGOs should provide core funding for NGO accountability efforts. Doubtless they have and will.

In summary, there is considerable agreement among commentators that NGOs do exercise power of sorts and that NGO activities in global governance need to be more accountable because the possibility of abuse exists. As Grant and Keohane note, NGO power cannot be justified as being delegated power from the world population or being power transmitted through an election. One reason why the NGO role sometimes elicits hostility is that NGOs may boast more legitimacy and a broader rule than the facts would justify. An NGO may legitimately advocate what it believes would be in the community interest, and as Gary Johns points out, but an NGO should claim no more than to represent a view. What puts NGOs on thin ice, however, is the claim to represent civil society or global public opinion. If NGOs were more careful not to make absurdly broad claims about themselves, their activist role might be less controversial.

Another important theme among commentators such as Grant and Keohane, Moravcsik, Spiro, and Wapner is that adequate global accountability may be lacking among all of the institutions engaged in global governance and also that accountability itself should be looked at as a comparative phenomenon. Thus, as Wapner explains, one should expect the attributes of accountability for NGOs to be different than for states or others.

Kingsbury is surely correct in calling for a richer international constitutionalism to address issues of accountability, mandate, and participation on a global scale. Although I have no problem with the concept of "First Amendment liberalism" as justifying why states should not interfere with NGOs, I believe that the universal values of human liberty and self-determination involved may be

\footnotetext{
${ }^{97}$ See www.ceres.org.
} 
overlooked in using a term associated so closely with American constitutionalism. Perhaps a better term might be "Part III liberalism" which is a reference to the applicable provisions in the International Covenant on Civil and Political Rights. ${ }^{98}$ The Covenant, Article 19, states: "Everyone shall have the right to freedom of expression; this right shall include freedom to seek, receive and impart information and ideas of all kinds, regardless of frontiers, either orally, in writing or in print, in the form of art, or through any other media of his choice. ${ }^{99}$ Article 21 states: "The right of peaceful assembly shall be recognized." ${ }^{100}$ Article 22 states, in part:

1. Everyone shall have the right to freedom of association with others, including the right to form and join trade unions for the protection of his interests.

2. No restrictions may be placed on the exercise of this right other than those which are prescribed by law and which are necessary in a democratic society in the interests of national security or public safety, public order (ordre public), the protection of public health or morals or the protection of the rights and freedoms of others ${ }^{101}$

None of these rights seem expressly inapplicable to the relationship between an individual and an international forum such as the United Nations. The situation may be different for the right to participate referred to in Article 25 which seems to hinge upon citizenship:

Every citizen shall have the right and the opportunity, without any of the distinctions mentioned in article 2 and without unreasonable restrictions:

\footnotetext{
${ }^{98}$ International Covenant on Civil and Political Rights, 16 Dec. 1966, 999 UNTS 171.

${ }^{99}$ Id. art. 19.2. The following provision states that: "The exercise of the rights provided for in paragraph 2 of this article carries with it special duties and responsibilities. It may therefore be subject to certain restrictions, but these shall only be such as are provided by law and are necessary: (a) For respect of the rights or reputations of others; [and] (b) For the protection of national security or of public order (ordre public), or of public health or morals. Id. art. 19.3.

${ }^{100}$ Id. art. 21. The provision continues: "No restrictions may be placed on the exercise of this right other than those imposed in conformity with the law and which are necessary in a democratic society in the interests of national security or public safety, public order (ordre public), the protection of public health or morals or the protection of the rights and freedoms of others."

${ }^{101}$ Id. art. 22.
} 
(a) To take part in the conduct of public affairs, directly or through freely chosen representatives; . . . . ${ }^{102}$

It is beyond the scope of this paper to do a detailed analysis of the liberalism provided for in the Covenant compared to that of the First Amendment, and its tensions, in the context of the exercise of rights on the international plane. ${ }^{103}$ One might note, however, that unlike the First Amendment, the Covenant does not explicitly use the language of a right "to petition the government for a redress of grievances," nor does it use the language "freedom of speech." In that context, it is interesting to note that the Charter of Fundamental Rights of the European Union does mention "the right of every person to be heard, before any individual measure which would affect him or her adversely is taken . . .", but this "Right to good administration" is cabined to the "institutions and bodies of the Union." 104 Similarly the "Right to petition" in the Charter applies only to the European Parliament. ${ }^{105}$ Although the degree of NGO accountability today may not be sufficient, many commentators - such as Grant and Keohane, Spiro, Wapner, and Florini-point out the numerous mechanisms and pressures that actually do promote NGO accountability and responsibility. All of the commentators recognize that NGO accountability as a concept remains roughly defined. Spiro offers an important distinction in distinguishing between internal and external accountability and this distinction seems to have been picked up in the recent analysis by Sustainability. The vertical distinction offered by Edwards is similar in some ways to Spiro's point but the categories of internal/external and up/down do not overlap. Slim too makes a useful analytical

\footnotetext{
${ }^{102}$ Id. art. 25. The remainder of this article refers to voting and public service.

${ }^{103}$ Of course, a citizen of the United States seeking to take part in the conduct of public affairs in the United Nations is perforce seeking to take part in U.S. public affairs, since the United States is a member of the United Nations.

${ }^{104}$ Charter of Fundamental Rights of the European Union, 2000/C364/01, art. 41.1, 41.2.

${ }^{105}$ Id. art. 44.
} 
distinction in suggesting the need for maps of stakeholders that will differ by the type of NGO activity involved. That idea is related to Spar and Dail's suggestion for a typology of NGO functions. All of the commentators agree on is the need for more transparency of NGOs and more reporting on their activities.

One suggestion offered by Spiro and Edwards that I do not find persuasive is the idea of a bargain or quid pro quo whereby NGOs get greater access in return for greater accountability. While I would agree with Edwards that "structured experimentation" can be useful, I cannot endorse the recommendation of the UN Panel of Eminent Persons that urges the U.N. Secretariat to engage NGOs in discussion about codes of conduct and self-policing mechanisms. In my view, the heavy hand of U.N. bureaucracy would exert a negative influence and the way to promote better NGO behavior is through the likely continuation of present trends of increased market-driven attention by NGOs to their own performance and creative efforts by NGOs to evaluate one another. The incursion of the WTO into NGO operations through the TBT Agreement is a little-noticed phenomenon and while there is nothing inherently wrong with the norms being proffered for standardizing organizations, it is unfortunate that the WTO itself does not yet practice what it preaches on matters such as developing a national consensus that builds up or providing a public notice and comment period for rulemaking.

\section{The NGO Accountability Challenge}

Without a doubt, NGOs in general need to improve their governance, management, and performance and to be subject to more sophisticated and systematic independent evaluations. The same observation is applicable to all non-profits, such as universities, not just NGO non-profits. It is also applicable to profitmaking entities. It is also applicable to governments. It is also applicable to international organizations and transgovernmental networks.

We live in an age of standard-setting and no doubt those who run NGOs, or fund NGOs, or belong to NGOs could benefit from standards, best practices, codes of conduct, and certification 
designed specifically for various types of NGOs. A great deal of effort in that direction is ongoing. For example, Social Accountability International (SAI) has been asked by InterAction, an umbrella group of international charities, to inspect and certify the tsunami-related child sponsorship programs of five major NGOs (e.g., Save the Children U.S.). ${ }^{106}$ The certification requires allowing SAI to inspect documents and field activities, and also examines some governance issues such as director conflicts of interest, accuracy of advertisements, and a 35 percent cap on administrative and fundraising costs relative to total expenditures.

Accountability more narrowly understood may presuppose relevant and agreed standards but, as noted above, accountability more broadly defined can be sought without clearly-defined standards. The idea that NGOs active in global governance lack sufficient accountability has become conventional wisdom and I would guess that the highest waves of accountability demands on civic society have yet to hit the shores. Writing in 1997, I suggested that the impact and influence of NGOs in the international arena may be a cyclical phenomenon. ${ }^{107}$ Certainly, over the past few years, criticism of NGOs has sharply increased but whether this has translated into a drop in influence remains unclear.

In my view, NGOs are extremely sensitive to threats to their influence and will take steps to obviate those threats. Recognizing that NGO influence is now being undermined to some extent by demands for greater NGO accountability, I would predict that NGOs will be eager to cooperate in the expansion of the supply of accountability mechanisms. So more efforts to improve accountability are on the way and will occur through most, if not all, of the six mechanisms of accountability noted by Grant and Keohane, namely, hierarchical, supervisory, fiscal, legal, market, and peer. For example,

\footnotetext{
${ }^{106}$ Michael M. Phillips, Big Charities Pursuing Certification To Quell Fears of Funding Abuses, Wall Street Journal, 9 March 2005, at A1.

${ }^{107}$ Steve Charnovitz, Two Centuries of Participation: NGOs and International Governance, 18 Mich. J. Int'1 L. 183, 268-7 (1997).
} 
legal accountability can relate to the laws of the territories in which NGOs are incorporated or operate, and can include laws relating to tax-exempt status, financial management, employer obligations, and deceptive and fraudulent practices. ${ }^{108}$ When NGO activities include actions rather than just words, for example, ecoterrorism, legal accountability will also include adherence to criminal laws. As Grant and Keohane point out, peer accountability can be especially important for NGOs because a poor record can impede efforts by an NGO to partner with others. ${ }^{109}$ Also they correctly point out that "market accountability" will be an important constraint on NGOs because they operate in a market for donors. ${ }^{110}$

Accountability mechanisms need to be tailored to NGO functions. Thus, when NGOs deliver services (e.g., immunizations) to individuals, the optimal form of accountability of that function will be different from the accountability of the same NGO carrying out a different function such as public education or advocacy. No systematic typology of NGO functions has come to my attention, ${ }^{111}$ but the classifier would need to consider the differences between functions such as standardization, labeling, intelligence collection and analysis, representation of workers, selling in the market, buying in the market, and various democracy-enhancement services such as raising the quality of debate or improving deliberation.

The differences between the NGO as a market participant and as a political actor would also shape the appropriate accountability mechanism. Thus, when NGOs perform functions similar to

\footnotetext{
${ }^{108}$ See, e.g., Nina J. Crimm, High Alert: The Government's War on the Financing of Terrorism and its Implications for Donors, Domestic Charitable Organizations, and Global Philanthropy, $45 \mathrm{Wm}$ and Mary L. Rev. 1341 (2004).

${ }^{109}$ See Grant \& Keohane, supra note 18 , at 37.

${ }^{110}$ Id. at 38 .

${ }^{111}$ A new, excellent paper analyzing NGO roles is Hildy Teegen, Jonathan P. Doh \& Sushil Vachani, The Importance of Nongovernmental Organizations (NGOs) in Global Governance and Value Creation: An International Business Research Agenda, 35 J. Int'1 Bus. Stud. 463 (2004).
} 
profitseeking entities, the regulation and accountability should be similar. This would apply, for example, to NGOs as contractors, employers, and providers of services to individuals.

The functions that present the real conceptual challenge for accountability and regulation are the NGO's role as a political actor. There the concern is that NGOs lack the restraints that apply to other institutions such as the market or the ballot box. Yet as Grant as Keohane note, in reality, NGOs are subject to a large number of constraints. As voluntary organizations, NGOs depend upon individuals who choose to belong to them, to work for them, to fund them, and to listen to them. But the accountability concern for NGOs is that their impact may go far beyond the individuals who take part in it. Contrast for example Amnesty International with Toastmasters in terms of impact on nonparticipants.

When any government regulation is considered, the first question to ask is what the market/non-market failure is and whether government intervention can help to correct it. On the issue of the global political activities of NGOs, I am skeptical that more oversight and regulation by governments or international organizations would be constructive. In my view, Pope Leo XIII was right when he warned that the state "should not thrust itself" into societies and citizens banded together in accordance with their rights. Government bureaucrats and politicians do not have any special competence to oversee NGO politics and guide them toward attainment of the common good. It may be that a threat of government regulation will induce some useful self-reform of errant NGO behavior, but in general I believe that if an action is wrong in the first place, then threatening to do it is also wrong.

An attempt to formulate a plan for greater government regulation of NGO political activities would run into many problems, starting with the trammels of statism. Government regulation tends to be territorial but this does not match up well with the domain of NGO action which can be global or with the membership and participants in an NGO which can be transnational. The difficulty of this spatial challenge tends to be underestimated by those who would like to see greater NGO 
accountability to someone or something. It is one thing to say that Global Witness, for example, needs to be more accountable, but quite another to specify to what sovereign authority that accountability should be owed.

It might be logical to imagine that the solution for transnational NGOs is to make them accountable to international organizations, but a moment's reflection would show the impracticality of that path.

On the other hand, some international organizations might play a useful role in overseeing efforts to develop standards for NGOs or voluntary codes of conduct for them. Beginning in 2002, the International Law Commission (ILC) began a project on the Responsibility of International Organizations and once that is completed, it is possible to imagine proposals for an ILC project on the Responsibility of NGOs. The ILC is supposedly accountable to the General Assembly but just about everyone is a stakeholder in its work, and the ILC has not yet adopted a suitably expansive view of its own accountability. For example, the ILC does not solicit public comments on its various draft articles.

As Grant and Keohane note, there are two models for accountability by those who entrust an entity with power-(1) principal-agent and (2) trustee. Both can be applicable to the relations between an NGO and its overseeing government, its funders, its members, its governing board, and its staff, but the trustee model might be the more useful one. For both models, however, the principal corrective in a voluntary organization would be exit or voice rather than efforts to enforce a particular norm. The members of a large NGO probably want the organization to develop expertise and utilize it for the purposes of the organization. The members understand that they are usually not capable of knowing on any given issue whether what the NGO says is right, but if evidence comes to light that the NGO is often making mistakes, then the members will get concerned.

Although the real issue in NGO accountability is whether the NGO is thoughtful, accurate, and fair in its statements, most of the attention to NGO accountability has been on a different issue- 
that is, whether the NGO is representative of its members. To me, representativeness is just a red herring. If the ideas being propounded are completely wrong, then the NGO for that reason is lacking in accountable to the community. In other words, I would give much more weight to how useful the ideas are that emanate from an NGO than I would give to whether the ideas faithfully represent the views of the NGO's membership. For example, some observers might be happy for the Flat Earth Society to advocate flat earth policies so long as the Society's leadership reflects the views of the members, but I would not. For a more painful example, consider the most notorious NGO today, Al Qaeda which may be a faithful representative of its followers.

If the adequacy of the NGO's representation of membership was ever a useful indicia of the NGO's accountability, surely the age of the internet and blogs changes that. For any powerful idea, for example, creationism, a coordinator can put together many people in many countries who will support it. Such a virtual NGO might not have any organization in the traditional sense but would be fully justified in saying that it faithfully represented its uniformly-thinking members. But surely the repetition or amplification of mistaken views is hardly sufficient for NGO accountability.

Although much NGO activity occurs in traditional affinity organizations, we often see a phenomenon whereby the potential impact of governmental decisions creates a new constituency concerned about it. ${ }^{112}$ Individuals who may have little in common with each other will join an organization to promote a particular cause that unites them. Such temporary, single-issue organizations may be highly representative of membership, but their accountability should be judged more substantively.

The unhelpfulness of an inquiry into the representativeness of an NGO can also be seen by considering the smallest of the NGOs-namely, the NGIs, the activist non-governmental individuals. For example, Raphael Lempkin had a great deal of positive impact on international law without

${ }^{112}$ See Loren A. King, Deliberation, Legitimacy, and Multilateral Democracy, 16 Governance 23, 43 (Jan. 2003). 
anyone asking whether he adequately represented himself. His impact came because of the power of his ideas.

Just as we know, and as Margaret Mead reminded us, that even one person can make a difference, we also know that the quantity of members of an NGO does not reveal much about the quality of the NGO's ideas. Nevertheless, NGO leaders are prone to boast about the size of their memberships as if that infused the NGO with a greater legitimacy than it would otherwise have. In my view, numbers matter when votes are counted but should not matter when ideas are weighed.

Although I have opposed making NGOs more accountable for their ideas to government regulators, I do not mean to suggest that governments lack tools to improve NGO accountability. The best way to constrain errant NGO ideas is to improve the marketplace of ideas in global policymaking. At present, this market is far from perfect and governments can undertake some fruitful improvements.

Inspiration can come from many founts of western political thought. One might recall James Madison in Federalist No. 51 who suggested that the "policy of supplying, by opposite and rival interests, the defect of better motives, might be traced through the whole system of human affairs, private as well as public." ${ }^{113}$ Or Alexis de Tocqueville who perceived that political associations “... by stimulating competition, [could be used] to discover the arguments most likely to make an impression on the majority ...."114 Or Immanuel Kant who counseled that the legislative authority of a nation should seek instruction from philosophers concerning the principles on which it should act toward other nations, and should recognize that allowing the class of philosophers to speak publicly "is indispensable to the enlightenment of their affairs." $" 15$

\footnotetext{
${ }^{113}$ The Federalist Papers, No. 51.

${ }^{114}$ Tocqueville, supra note 6, Vol. 1, Part II, Chapter 4.

${ }^{115}$ Immanuel Kant, To Perpetual Peace, 1795, (Kant pagination 369).
} 
Several years ago, Daniel Esty formulated a normative theory as to how NGOs could help the WTO consider competing policy options. ${ }^{116}$ He explained that “An NGO-enriched WTO decision process would offer better competition for national governments in the search for optimal policies."117 I believe that Esty's theory has more general applicability to global governance well beyond the WTO.

In seeking to promote a more robust competition of ideas, governments can structure the deliberative processes in intergovernmental and transnational fora so that contesting NGOs can debate with each other and with business groups. The idea that the quality of NGO participation would improve if the discursive interface improves can be seen in the analyses of Wapner, Spiro, and Edwards. Spiro contributes the suggestion of accountability to "the system." New experiments in multistakeholder dialogues, for example at the Monterrey Summit, have promoted debate among disparate groups and can contribute to more responsible advocacy. In that regard, one might recall that the original idea in 1919 for establishing a mechanism by which NGOs of different colors could debate ideas - the Constitution of the ILO which provides a role for employer and worker delegates in the formation of international labor conventions and recommendations. In addition to this horizontal interface, Edwards adds the useful notion of vertical accountability, namely, that on development issues, the claims made by the large NGOs should be rooted in the experience at the local level. ${ }^{118}$

\section{Summary}

Governments should not try to directly regulate the quality of advocacy of NGOs, but rather should improve it indirectly by establishing mechanisms that give NGOs an incentive to upgrade

\footnotetext{
${ }^{116}$ Daniel C. Esty, Non-Governmental Organizations at the World Trade Organization: Cooperation, Competition, or Exclusion, 1 JIEL 123 (1998).

${ }^{117}$ Id. at 137.

${ }^{118}$ Edwards, supra note 56, at 19-26.
} 
their own performance. NGOs are very likely to be criticizing governments and it will be difficult for governments to appear to be objective were they to insist that NGO statements be honest and fair.

The idea of providing better mechanisms for NGO debate works well whether the issues are technical/scientific or hinge on values. The WTO benefited enormously from the intellectual contributions of health NGOs (and Fred Abbott) who pointed out that the trade rule for compulsory licensing of patents could prevent a supply of essential medicines from being available to countries without a manufacturing capacity. ${ }^{119}$ That point was an economic and technical one. The NGO critics of TRIPS also raised more general concerns about whether the WTO rules for patenting took sufficient account of health values. Over many decades, NGOs have shown themselves to be adapt in advocacy on both the narrower technical points and the broader claims on values.

A great deal of literature exists on the so-called "trade-and" debates, such as trade and environment, trade and health, or trade and human rights. I think that some of this literature has been insufficiently attentive to the broader phenomenon of cross-fertilization of international law whereby the norms of one body of law are infiltrated into the other. Over the past 15 years, we have seen how environmental norms have found a way themselves into WTO jurisprudence and how trade norms have found their way into environmental treatymaking (e.g., biosafety). This is all to the good. Some other examples are the application of human rights norms to the laws of war, the application of state responsibility to international organizations, and attempted application of development objectives to international intellectual property law. Just as private corporations are being subjected to claims of triple bottom line and corporate social responsibility, similar tranfigurational ideas are being applied to international organizations and their treaties. In my view, it is the NGOs, acting as “transnational norm entrepreneurs," who, along with the publicists, are leading the way in these developments.

\footnotetext{
${ }^{119}$ See the Agreement on Trade-Related Aspects of Intellectual Property Rights (TRIPS), art. 31(f).
} 
In the critiques of NGOs, one subtext seems to be that NGOs are pursuing only a "partial" interest (or a single-issue campaign), and perforce NGOs will not be accountable to the public as a whole which will be motivated by general interests. Assuming that this is true and a problem, the solution might be to pay less attention to the NGOs or to mandate altruism. In my view, that is the wrong diagnosis and the wrong solution. It is the wrong diagnosis because partiality or private interest can operate as a virtue not only in markets but also in polities. There is certainly a place for constitutional rules to tie government hands in order to make them less susceptible to the entreaties of the special interests, but in my view, such constitutional rules should not include muzzling the private voice. It is the wrong solution because authoritative decisionmakers need a constant infusion of competitive ideas and values in order to make complex decisions in the best interest of the global community. Or to quote Tocqueville, "A government, by itself, is equally incapable of refreshing the circulation of feelings and ideas among a great people, as it is of controlling every industrial undertaking." $" 120$

${ }^{120}$ Tocqueville, supra note 6, Vol. 2, Part II, Chapter 5. 